\title{
Bond-Slip Behavior of Basalt Fiber Reinforced Polymer Bar in Concrete Subjected to Simulated Marine Environment: Effects of BFRP Bar Size, Corrosion Age, and Concrete Strength
}

\author{
Yongmin Yang, ${ }^{1,2}$ Zhaoheng Li, ${ }^{1,2}$ Tongsheng Zhang, ${ }^{1}$ Jiangxiong Wei, ${ }^{1}$ and Qijun Yu ${ }^{1}$ \\ ${ }^{1}$ School of Materials Science and Engineering, South China University of Technology, Guangzhou 510640, China \\ ${ }^{2}$ Guangdong Research Institute of Water Resources and Hydropower, Guangzhou 510635, China \\ Correspondence should be addressed to Qijun Yu; concyuq@scut.edu.cn
}

Received 23 September 2016; Revised 7 January 2017; Accepted 22 February 2017; Published 26 March 2017

Academic Editor: Baolin Wan

Copyright (C) 2017 Yongmin Yang et al. This is an open access article distributed under the Creative Commons Attribution License, which permits unrestricted use, distribution, and reproduction in any medium, provided the original work is properly cited.

Basalt Fiber Reinforced Polymer (BFRP) bars have bright potential application in concrete structures subjected to marine environment due to their superior corrosion resistance. Available literatures mainly focused on the mechanical properties of BFRP concrete structures, while the bond-slip behavior of BFRP bars, which is a key factor influencing the safety and service life of ocean concrete structures, has not been clarified yet. In this paper, effects of BFRP bars size, corrosion age, and concrete strength on the bond-slip behavior of BFRP bars in concrete cured in artificial seawater were investigated, and then an improved Bertero, Popov, and Eligehausen (BPE) model was employed to describe the bond-slip behavior of BFRP bars in concrete. The results indicated that the maximum bond stress and corresponding slip decreased gradually with the increase of corrosion age and size of BFRP bars, and ultimate slip also decreased sharply. The ascending segment of bond-slip curve tends to be more rigid and the descending segment tends to be softer after corrosion. A horizontal end in bond-slip curve indicates that the friction between BFRP bars and concrete decreased sharply.

\section{Introduction}

Traditional reinforced concrete (RC) structures often encounter durability problems due to cracks caused by corrosion expansion of steel bar [1]. With respect to steel bar, Basalt Fiber Reinforced Polymer (BFRP) bars present superior corrosion resistance as a kind of novel nonmetallic reinforced bars with high chemical stability [2-5]. Recently, BFRP bars are regarded as a potential alternative material to replace traditional steel bar in reinforced concrete structures subjected to extreme corrosive environment, such as ocean concrete structures [6-10].

Numerous researches have been carried out on mechanical properties and bond durability of BFRP bars or BFRP reinforced concrete [11-14]. The tensile strength loss of BFRP bars was as high as $40 \%$ after immersion in $55^{\circ} \mathrm{C}$ alkaline solution for 63 days [11], and the bond strength of BFRP bars in concrete immersed in artificial seawater for 90 days exhibited a $25 \%$ reduction [12]. Tighiouart et al. [13] confirmed that it was easy bleeding at the interface between BFRP bars and concrete when the large diameter BFRP bars were used, resulting in a decreased bond strength between BFRP bars and concrete. Shen et al. [14] found that the bond strength of the BRFP bars in concrete remained essentially unchanged after exposure to $40^{\circ} \mathrm{C}$ artificial seawater for 60 days.

The bond-slip behavior, which affects bar anchoring, lap splice strength, concrete-cover requirement, serviceability, and ultimate states, is a key feature for the successful application of BFRP bars as internal reinforcement in concrete structures [15]. It should be noted that the bond-slip behavior of BFRP bars in concrete was different from that of steel bar $[16,17]$. Although some achievements about the bond-slip behavior between BFRP bars and concrete have been made [11, 16-24], most of them were focused on small size BFRP bars $(<\Phi 10 \mathrm{~mm})$. However, the bond-slip behavior between large size BFRP bars and concrete is different due to larger interfacial transition zone, internal bleeding, and smaller 


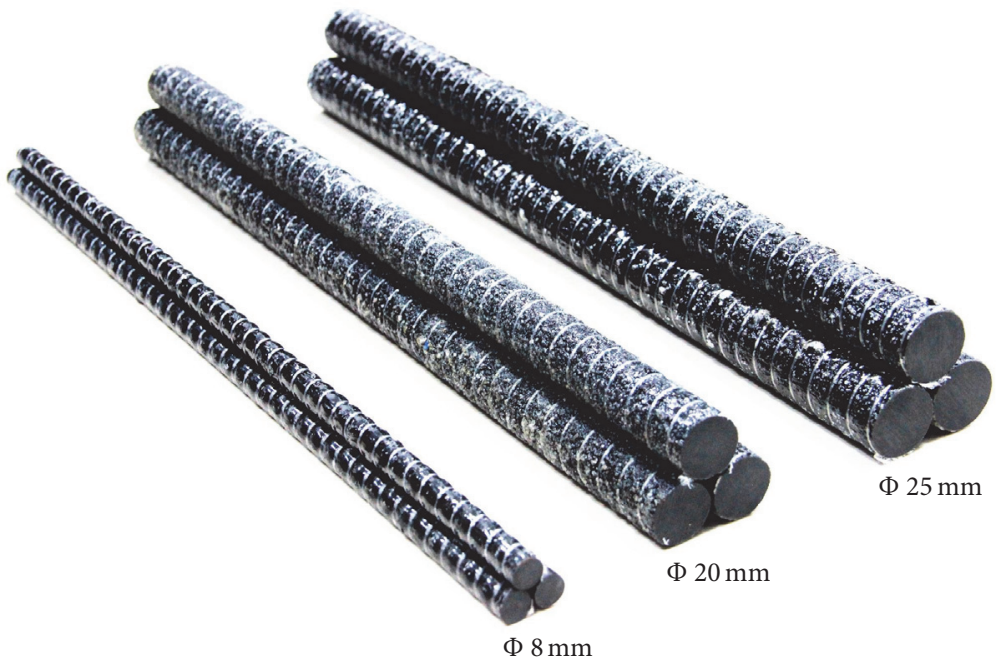

(a) Specimen photograph
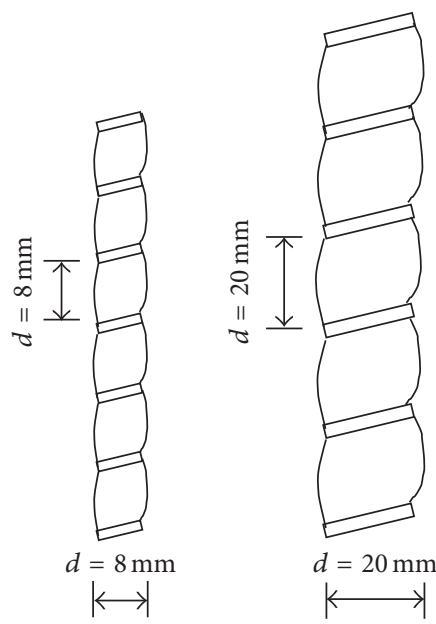

(b) Specimen geometry

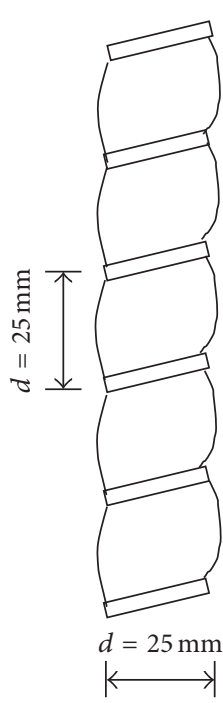

FIGURE 1: The photograph and the size of BFRP bars.

TABLE 1: The mechanical properties of the BFRP bars with different size.

\begin{tabular}{lccc}
\hline Size of BFRP bars & $\begin{array}{c}\text { Ultimate tensile strength } \\
(\mathrm{MPa})\end{array}$ & $\begin{array}{c}\text { Tensile elastic modulus } \\
(\mathrm{GPa})\end{array}$ & $\begin{array}{c}\text { Ultimate strain } \\
(\%)\end{array}$ \\
\hline$\Phi 8 \mathrm{~mm}$ & 1210 & 58.2 & 2.2 \\
$\Phi 20 \mathrm{~mm}$ & 1350 & 62.7 & 2.8 \\
$\Phi 25 \mathrm{~mm}$ & 1180 & 57.4 & 2.6 \\
\hline
\end{tabular}

specific perimeter. In addition, long term bond-slip behavior of BFRP bars in concrete exposed to marine environment has not been clarified yet.

Large size BFRP bars $(>\Phi 20 \mathrm{~mm}$ ) are expected to be used as reinforced material in ocean concrete structures, especially for south China coastal area. Therefore, effects of BFRP bars size, corrosion age, and concrete strength on the bond-slip behavior of BFRP bars in concrete subjected to artificial seawater were investigated in the present study, and an improved Bertero, Popov, and Eligehausen (BPE) model was employed to describe the bond-slip behavior of BFRP bars. The results will give a better understanding of bond-slip behavior of BFRP bars in concrete subjected to marine environment and finally provide fundamental data for the design and service life prediction of marine concrete structures.

\section{Materials and Methods}

2.1. Materials. Basalt filaments were pulled over a roller in the pultrusion process to form bars; then, the bars were coated with epoxy resin and twined with nylon wire $(\Phi 0.5 \mathrm{~mm})$. The epoxy resin was solidified immediately after adhering a layer of quartz sand on the bars. The obtained BFRP bars are regarded as desirable reinforcement material in corrosion environment due to their high strength, low weight, corrosion resistance, and cost performance [25]. BFRP bars with size of $\Phi 8 \mathrm{~mm}, \Phi 20 \mathrm{~mm}$, and $\Phi 25 \mathrm{~mm}$ were used as shown in Figure 1. Their mechanical properties measured according to ASTM D3039 [26] are listed in Table 1.

ASTM type II 42.5 Portland cement, river sand (fineness modules of 2.7), crushed limestone (particle size of $5.0 \mathrm{~mm}-31.5 \mathrm{~mm}$ ), tap water, and polycarboxylate superplasticizer (water reducing ratio of $25 \%$ ) were used to prepare concrete according to mixture proportions shown in Table 2, and 28-day compressive strength of concrete tested as specified in ASTM C39 [27] is also listed.

2.2. Specimen Preparation. The pullout specimen consisted of $600 \mathrm{~mm}$ long BFRP bars embedded centrally in concrete column $(\Phi 150 \mathrm{~mm} \times 150 \mathrm{~mm})$ as shown in Figure 2(a). The embedded length was kept constant at 5 times as the diameter of the BFRP bars according to FILEM/FIP recommendation RC6 [28], and PVC tube was used at the loading end of the bar to minimize the stress concentration near the loading plate. Steel pipes were used as anchors at the loading end and were cast with epoxy resin before casting. Fresh concrete was cast into the mould and then vibrated for 30 seconds (Figure 2(b)); demoulding was performed after curing at $20 \pm$ $1^{\circ} \mathrm{C}$ and $90 \%$ relative humidity chamber for $24 \mathrm{~h}$. The exposed 
TABLE 2: The mixture proportions of concrete prepared and their 28 days of compressive strength.

\begin{tabular}{lcccccc}
\hline Sample ID & $\begin{array}{c}\text { Cement } \\
\left(\mathrm{kg} / \mathrm{m}^{3}\right)\end{array}$ & $\begin{array}{c}\text { Sand } \\
\left(\mathrm{kg} / \mathrm{m}^{3}\right)\end{array}$ & $\begin{array}{c}\text { Stone } \\
\left(\mathrm{kg} / \mathrm{m}^{3}\right)\end{array}$ & $\begin{array}{c}\text { Water } \\
\left(\mathrm{kg} / \mathrm{m}^{3}\right)\end{array}$ & $\begin{array}{c}\text { Water-reducing } \\
\text { admixture }\left(\mathrm{kg} / \mathrm{m}^{3}\right)\end{array}$ & $\begin{array}{c}28 \text { days of } \\
\text { compressive } \\
\text { strength }(\mathrm{MPa})\end{array}$ \\
\hline C30 & 300 & 766 & 1149 & 165 & 4.5 & 43.8 \\
C40 & 350 & 729 & 1141 & 170 & 5.3 & 52.5 \\
C50 & 400 & 690 & 1127 & 173 & 6.0 & 64.0 \\
\hline
\end{tabular}

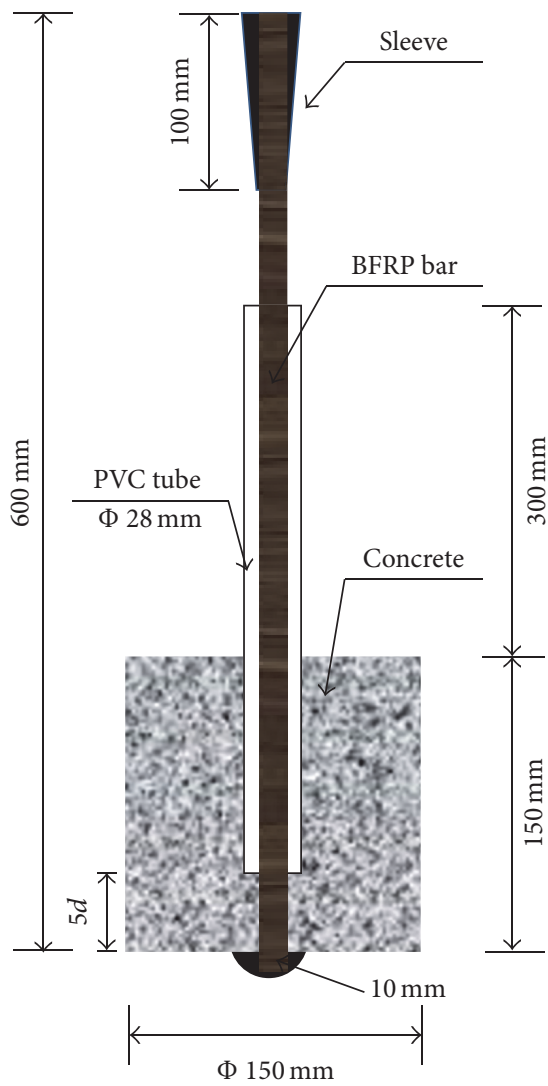

(a) Specimen geometry

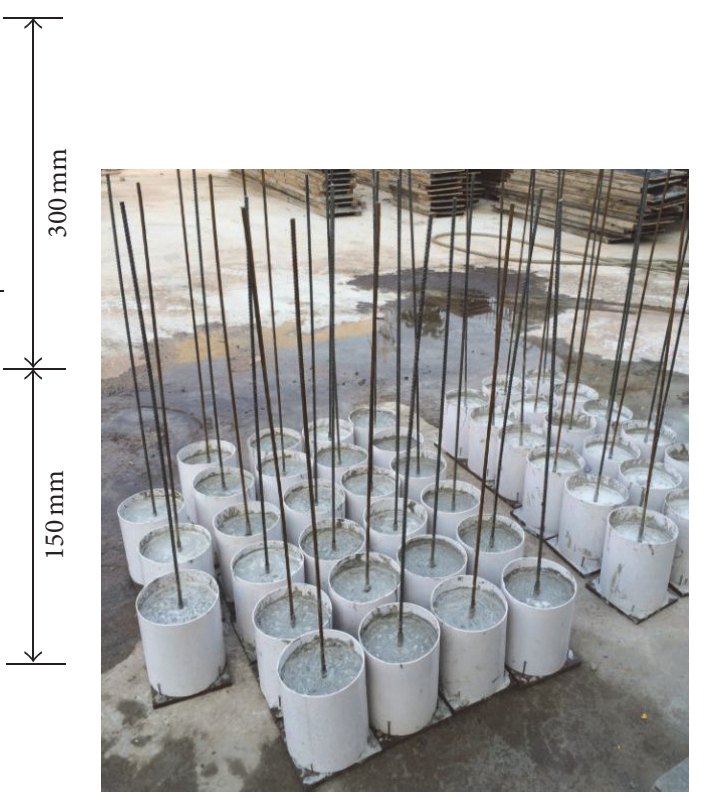

(b) Specimen photograph

FigURE 2: The geometry and photograph of pullout specimens.

free end of the bars was sealed by epoxy resin $(\Phi 10 \mathrm{~mm})$; the specimens were cured in lime-saturated water at $20 \pm$ $1^{\circ} \mathrm{C}$ for 27 days and then immersed artificial seawater $(\mathrm{NaCl}$ $24.53 \mathrm{~g} / \mathrm{L}, \mathrm{MgCl}_{2} 20 \mathrm{~g} / \mathrm{L}, \mathrm{Na}_{2} \mathrm{SO}_{4} 4.09 \mathrm{~g} / \mathrm{L}$, and $\mathrm{CaCl}_{2} 1.16 \mathrm{~g} / \mathrm{L}$ according to ASTM D 1141-98 [29]) under $40^{\circ} \mathrm{C}$; schematic of conditioning container and details are depicted in Figure 3.

2.3. Pullout Test Procedures. Figure 4 depicts the typical details and schematic for pullout test according to ASTM D7913 [30]. The tests were carried out with a MTS testing machine in displacement control mode at a rate of $2 \mathrm{~mm} / \mathrm{min}$. The displacements of the free end and loading end of BFRP bar were measured with linear variable displacement transducers (LVDT), and the applied load and displacements were recorded automatically throughout a data-acquisition system. The slip of the BFRP bars in concrete can be obtained as follows:

$$
s=s_{L}-s_{F},
$$

where $s$ is the slip of the BFRP bars $(\mathrm{mm}) ; s_{L}$ is the displacement of the loading end of the BFRP bars $(\mathrm{mm}) ; s_{F}$ is the displacement of the free end of the BFRP bars ( $\mathrm{mm})$.

The bond stress can be calculated assuming a uniform bond stress distribution along the embedded length of the bar in concrete using

$$
\tau=\frac{P}{\pi d L_{d}},
$$

where $\tau$ is the bond stress $(\mathrm{MPa}) ; P$ is the pullout force which was measured by pressure sensor $(\mathrm{N})$; $d$ is the diameter of 


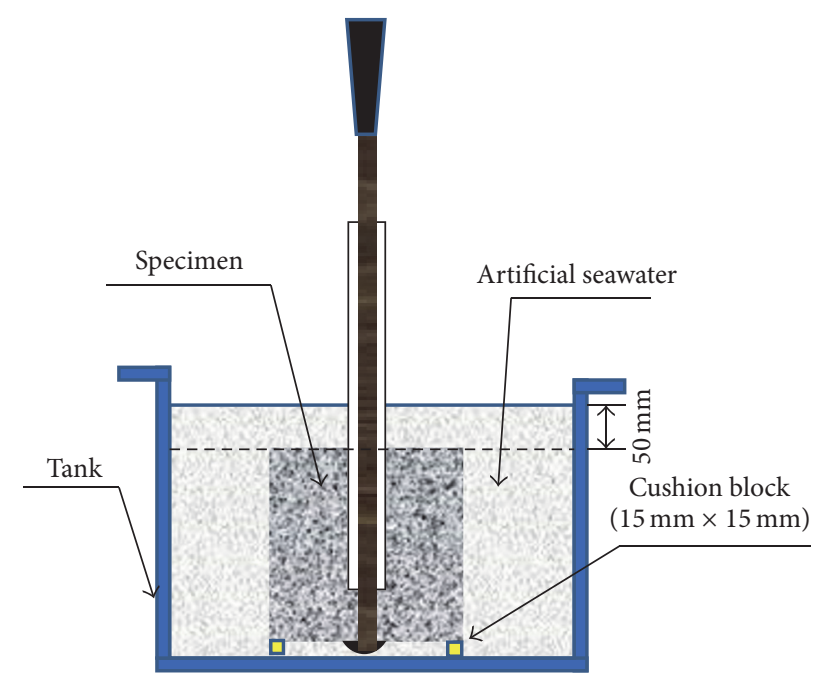

FIGURE 3: Schematic for specimens immersed artificial seawater.

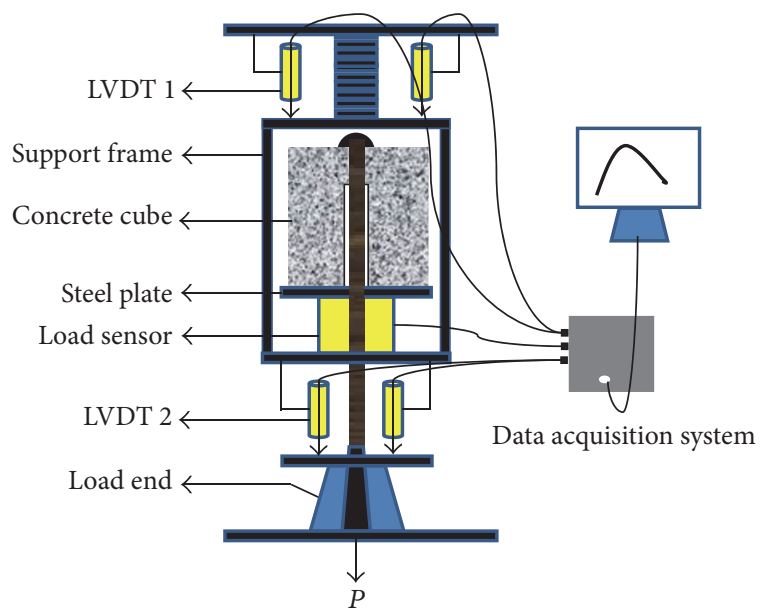

FIgURE 4: Apparatus of pullout test.

BFRP bars $(\mathrm{mm}) ; L_{d}(\mathrm{~mm})$ is bond length of the BFRP bars in concrete.

\section{Results and Analysis}

3.1. Effect of Corrosion Age on the Bond-Slip Behavior of BFRP Bars in Concrete. The bond-slip behavior of the BFRP bars in concrete shown in Figure 5 can be described by four parameters: $\tau_{1}$ and $s_{1}$ are the maximum bond stress and corresponding slip, while $s_{2}$ and $\tau_{2}$ are ultimate slip and corresponding bond stress. Both $\tau_{1}$ and $s_{1}$ decreased gradually with the increase of corrosion age. For instance, $\tau_{1}$ and $s_{1}$ of BRFP bars $(\Phi 25 \mathrm{~mm})$ in concrete before corrosion were $21.5 \mathrm{MPa}$ and $3.0 \mathrm{~mm}$ and reduced to $17.8 \mathrm{MPa}$ and $1.7 \mathrm{~mm}$ after 90 -day corrosion in artificial seawater, respectively, indicating that the maximum bond stress decreased with the prolong of corrosion age. $\tau_{2}$ of BRFP bars ( $\Phi 25 \mathrm{~mm}$ ) increased from 1.1 MPa to $8.1 \mathrm{MPa}$ after 90 days of corrosion, while $s_{2}$ was decreased sharply from $10.0 \mathrm{~mm}$ to $5.2 \mathrm{~mm}$. It should be noted that a horizontal end in bond-slip curve was observed after corrosion, which means significant reduction in ultimate slip after corrosion. Similar tendency was found for BRFP bars with size of $\Phi 8 \mathrm{~mm}$, and both $\tau_{1}, s_{1}$ and $\tau_{2}$, $s_{2}$ of BRFP bars with size of $\Phi 8 \mathrm{~mm}$ had higher value than those of BRFP bars with size of $\Phi 25 \mathrm{~mm}$.

3.2. Effect of Bars Size on Bond-Slip Behavior of BFRP Bars in Concrete. As shown in Figure 6, the maximum bond stress and corresponding slip decreased with the diameter increase of BFRP bars, and ultimate slip also decreased slightly. After 90 days of corrosion, both the maximum bond stress and corresponding slip of the BFRP bars decreased about $8.0 \%$. An obvious horizontal end was observed for all specimens after corrosion, indicating that the friction between BFRP bars and concrete decreased sharply.

\subsection{Effect of Concrete Strength on Bond-Slip Behavior of BFRP} Bars in Concrete. With the increase of concrete strength, the maximum bond stress increased gradually, while slip corresponds to maximum bond stress and ultimate slip decreased as shown in Figure 7. After 90 days of corrosion, both the maximum bond stress and corresponding slip of the BFRP bars increased with the increase of concrete strength. BFRP bars in high strength concrete had lager ultimate slip. It can be inferred that high strength concrete is benefit to the bond performance between BFRP bars and concrete.

\section{Discussion}

BPE model [31] is generally used to describe the bond-slip of steel bar in concrete (Figure 8(a)). The ascending segment $\left(s \leq s_{1}\right)$ of bond-slip curve can be expressed as follows:

$$
\frac{\tau}{\tau_{1}}=\left(\frac{s}{s_{1}}\right)^{\alpha} \quad\left(s \leq s_{1}\right),
$$

where $\tau_{1}$ is the maximum bond stress; $s_{1}$ is the corresponding slip; $\alpha$ is a curve-fitting parameter $(\alpha<1)$.

For a second segment with a constant bond $\left(\tau=\tau_{1}\right)$ up to a slip $\left(s=s_{2}\right)$, a linearly descending segment developed from $\left(s_{2}, \tau_{2}\right)$ to $\left(s_{3}, \tau_{3}\right)$; and a horizontal segment developed for $s>s_{3}$, with a value of $\tau$ due to the development of friction $\left(\tau=\tau_{3}\right)$.

Cosenza et al. proposed an improved BPE model to describe the bond-slip curve of FRP bars in concrete by ignoring the second segment (Figure 8(b)) [32]. The ascending segment is coincident with the original BPE model but the slope of descending segment is $p \cdot \tau_{1} / s_{1}$, which is given by

$$
\frac{\tau}{\tau_{1}}=1-p\left(\frac{s}{s_{1}}-1\right) \quad\left(s_{1} \leq s \leq s_{2}\right)
$$

where $p$ is parameter accounting for the softening, $s_{2}$ is the ultimate slip, and $s_{3}$ is friction slip due to bond resistance.

Obviously, the improved BPE model is more suitable to describe the bond-slip behavior of BRFP bars in concrete. The improved BPE model can be further described as $A_{r}, \alpha$, and 


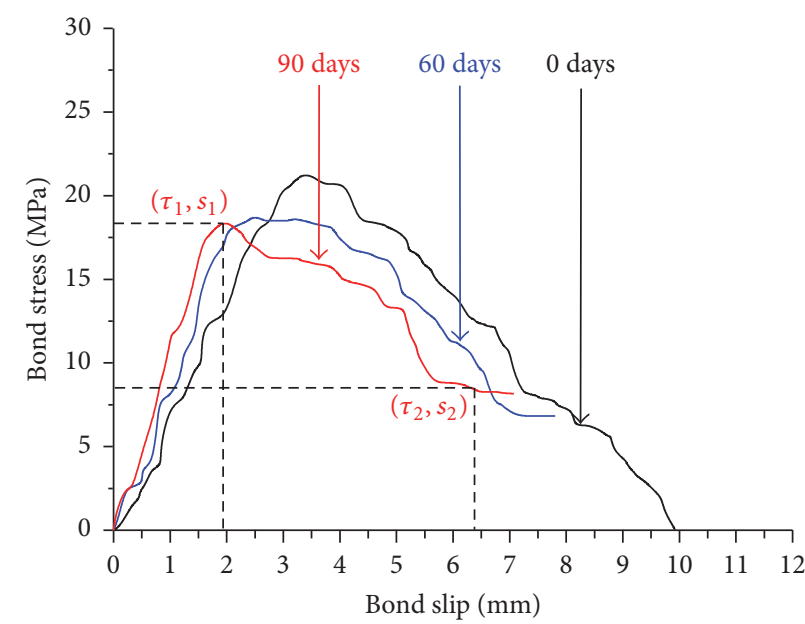

(a) $\Phi 8 \mathrm{~mm}$

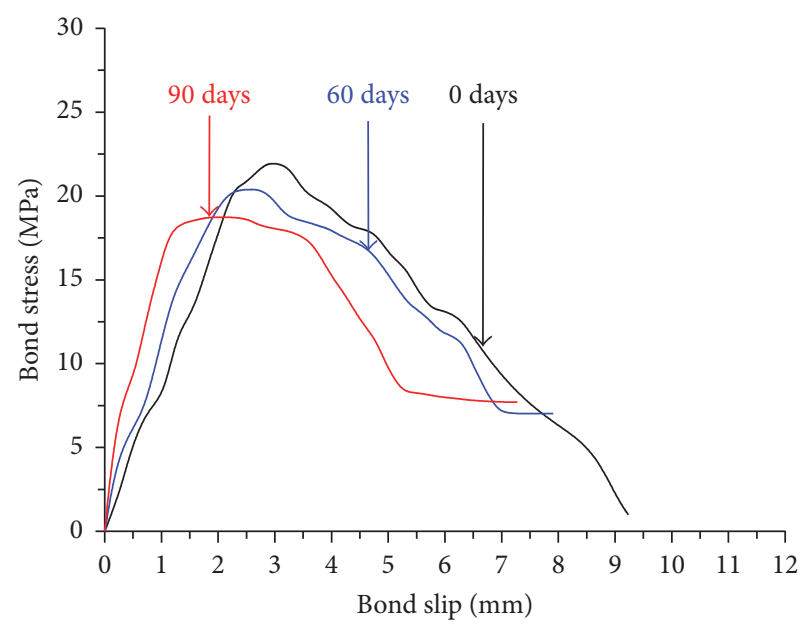

(b) $\Phi 25 \mathrm{~mm}$

FIGURE 5: Bond-slip behavior of the BFRP bars in concrete specimens after different corrosion ages.

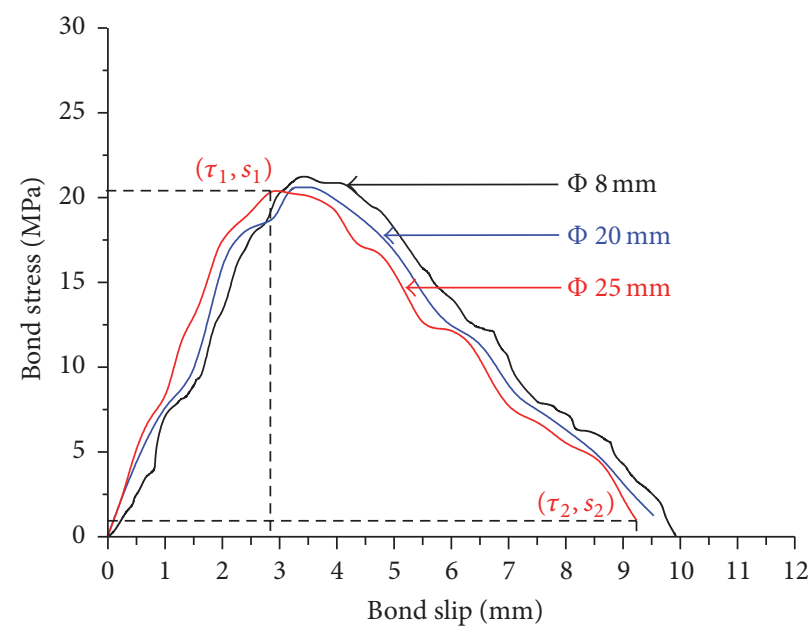

(a) Before corrosion

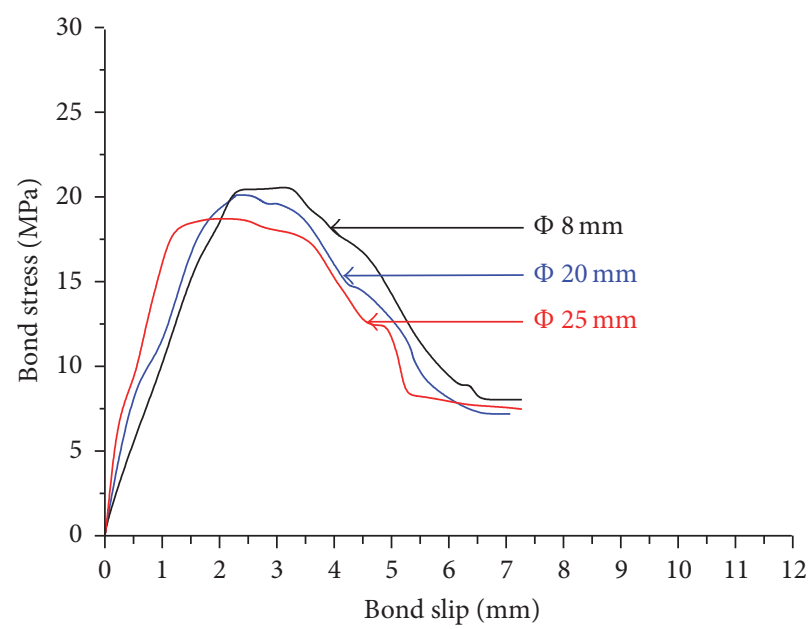

(b) After 90 days of corrosion

FIGURE 6: Bond-slip behavior of BFRP bars with different size in concrete specimens.

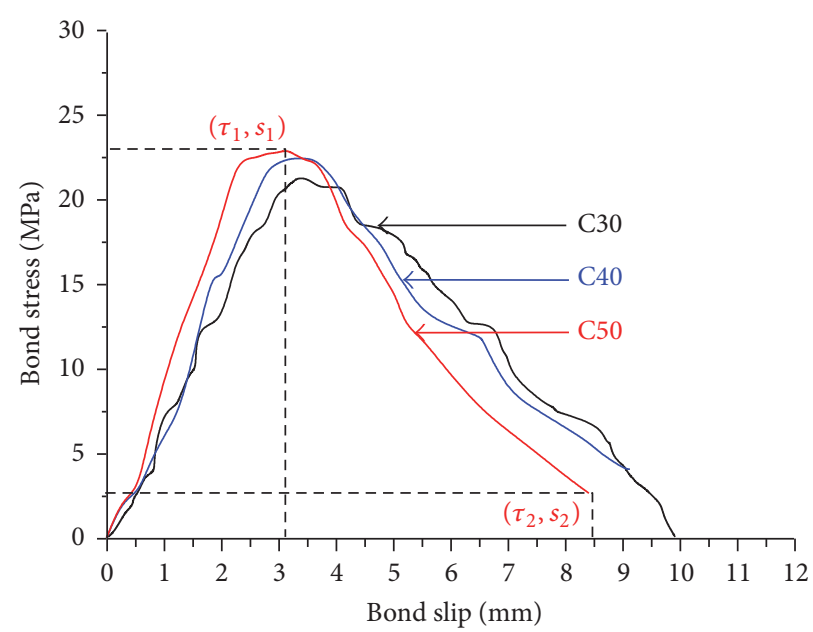

(a) Before corrosion

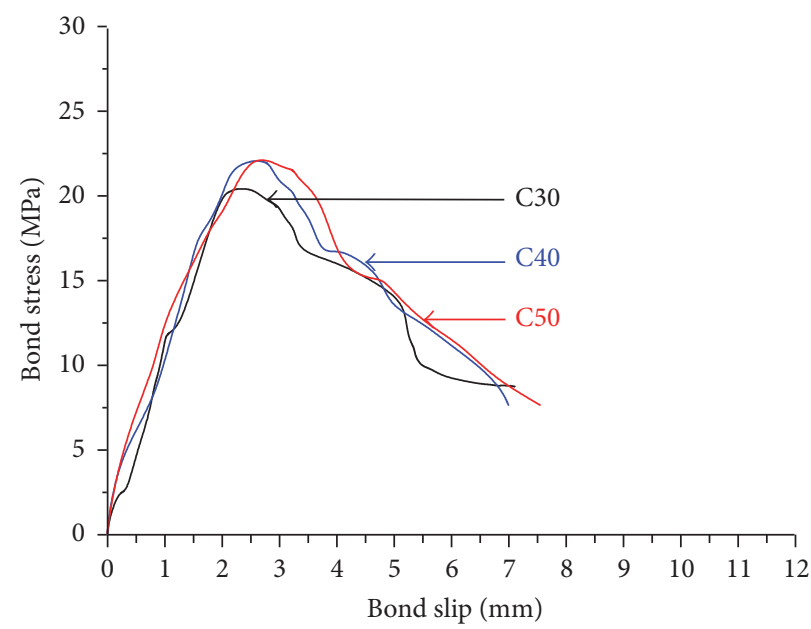

(b) After 90 days of corrosion

FIgURE 7: Bond-slip behavior of the BFRP bars in concrete with different strength grade. 


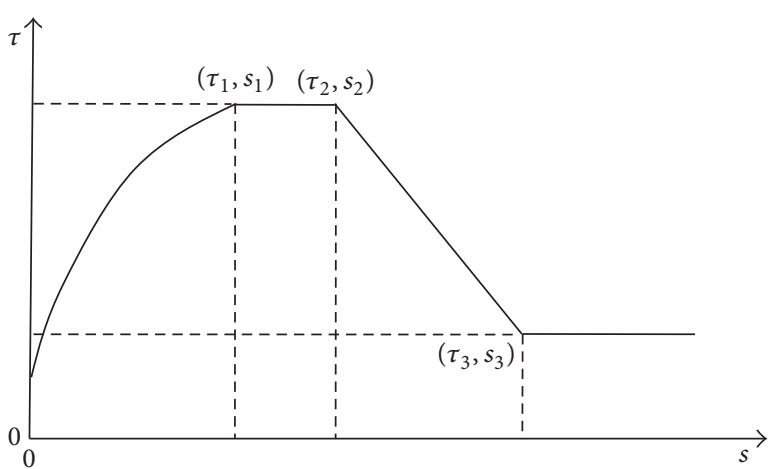

(a) Original BPE model

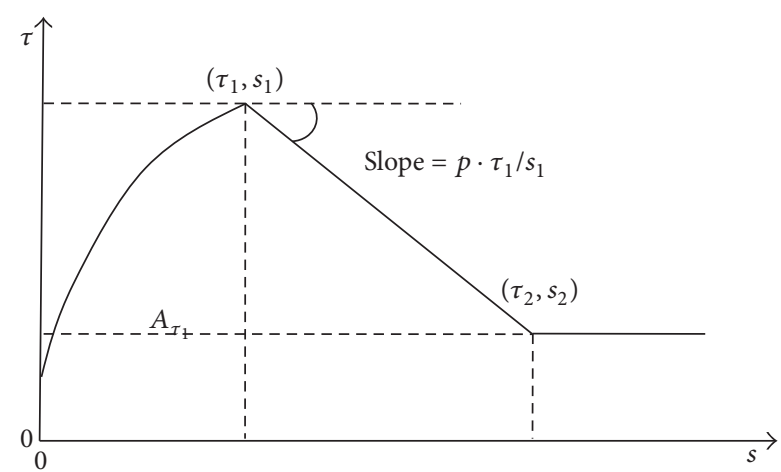

(b) Improved BPE model

Figure 8: Relationship between bond stress and slip in BPE Model.

TABLE 3: The parameters of bond-slip curves of the BFRP bars in concrete specimens after different corrosion ages.

\begin{tabular}{|c|c|c|c|c|c|}
\hline Size of BFRP bars & $\begin{array}{c}\text { Age of corrosion } \\
\text { (days) }\end{array}$ & $\begin{array}{c}\tau_{1} \\
(\mathrm{MPa}) \\
\end{array}$ & $\begin{array}{c}s_{1} \\
(\mathrm{~mm})\end{array}$ & $\begin{array}{c}\tau_{2} \\
(\mathrm{MPa}) \\
\end{array}$ & $\begin{array}{c}s_{2} \\
(\mathrm{~mm})\end{array}$ \\
\hline \multirow{3}{*}{$\Phi 8 \mathrm{~mm}$} & 0 & 22.5 & 3.5 & 1.2 & 9.2 \\
\hline & 60 & 20.8 & 2.9 & 7.6 & 7.5 \\
\hline & 90 & 20.0 & 2.0 & 11.0 & 5.6 \\
\hline \multirow{3}{*}{$\Phi 25 \mathrm{~mm}$} & 0 & 21.5 & 3.1 & 1.1 & 10.0 \\
\hline & 60 & 20.0 & 2.5 & 6.4 & 6.7 \\
\hline & 90 & 17.8 & 1.7 & 8.1 & 5.2 \\
\hline
\end{tabular}

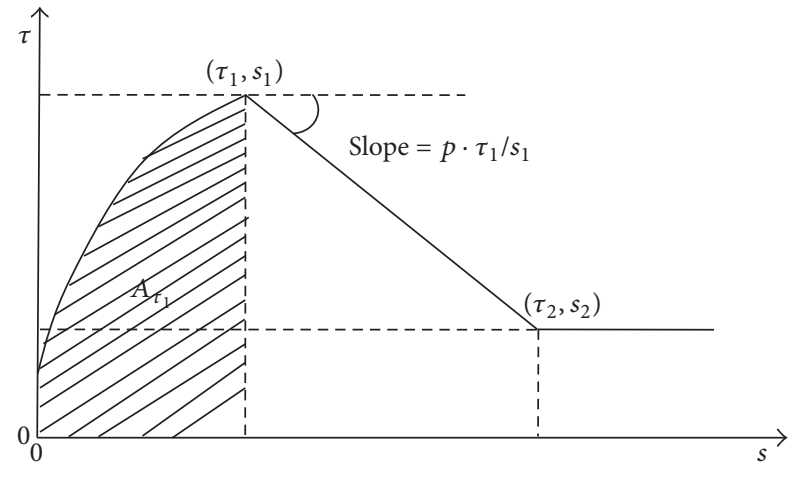

FIgURE 9: Geometrical schematic of improved BEP model.

$p$, and $A_{r}$ (area underneath the ascending segment as shown in Figure 9) can be written as follows:

$$
A_{r}=\int_{0}^{s_{1}} \tau(s) \cdot \mathrm{d} s=\int_{0}^{s_{1}} \tau_{1}\left(\frac{s}{s_{1}}\right)^{\alpha} \cdot \mathrm{d} s=\frac{\tau_{1} \cdot s_{1}}{1+a} .
$$

Then, $\alpha$ and $p$ in the improved BEP model can be calculated from $A_{r}$ by

$$
\begin{aligned}
& \alpha=\frac{\tau_{1} \cdot s_{1}}{A_{r}}-1, \\
& p=\frac{s_{2}-s_{1}}{\tau_{1}-\tau_{2}} \cdot \frac{s_{1}}{\tau_{1}} .
\end{aligned}
$$

It can be inferred that a low value of $\alpha$ means bond stress develops without significant slip, and the ascending segment can be well reproduced using a rigid law. For the descending segment, a low value of $p$ and $p \cdot \tau_{1} / s_{1}$ indicates larger slips, and the descending segment can be well fitted using a softening law. Tables 3-6 and Figure 10 showed that the ascending segment tends to be more rigid and the descending segment tends to be softer after corrosion, and the corrosion has much more significant effect on the bond-slip behavior of large size BFRP bars in concrete.

\section{Conclusions}

Main conclusions that can be drawn from the present study were as follows:

(1) The maximum bond stress and corresponding slip decreased gradually with the increase of corrosion age, and ultimate slip also decreased sharply from $10.0 \mathrm{~mm}$ to $5.2 \mathrm{~mm}$. A horizontal section in bondslip curve was observed after corrosion, indicating the friction between BFRP bars and concrete decreased sharply.

(2) The maximum bond stress and corresponding slip decreased with the diameter increase of BFRP bars, and ultimate slip also decreased slightly. Both the maximum bond stress and corresponding slip of the BFRP bars increased with the increase of concrete strength. BFRP bars in high strength concrete possessed larger ultimate slip.

(3) The ascending segment of bond-slip curve tends to be more rigid and the descending segment tends to 
TABLE 4: The parameters of bond-slip behavior of BFRP bars with different size in concrete specimens.

\begin{tabular}{|c|c|c|c|c|c|}
\hline Size of BFRP bars & $\begin{array}{c}\text { Age of corrosion } \\
\text { (days) }\end{array}$ & $\begin{array}{c}\tau_{1} \\
(\mathrm{MPa}) \\
\end{array}$ & $\begin{array}{c}s_{1} \\
(\mathrm{~mm})\end{array}$ & $\begin{array}{c}\tau_{2} \\
(\mathrm{MPa}) \\
\end{array}$ & $\begin{array}{c}s_{2} \\
(\mathrm{~mm})\end{array}$ \\
\hline \multirow{2}{*}{$\Phi 8 \mathrm{~mm}$} & 0 & 22.5 & 3.5 & 1.2 & 9.2 \\
\hline & 90 & 20.8 & 2.9 & 7.6 & 7.5 \\
\hline \multirow{2}{*}{$\Phi 20 \mathrm{~mm}$} & 0 & 21.8 & 3.3 & 1.1 & 9.3 \\
\hline & 90 & 20.6 & 2.6 & 7.0 & 6.9 \\
\hline \multirow{2}{*}{$\Phi 25 \mathrm{~mm}$} & 0 & 21.5 & 3.1 & 1.1 & 10.0 \\
\hline & 90 & 20.0 & 2.5 & 6.4 & 6.7 \\
\hline
\end{tabular}

TABLE 5: Parameters of bond-slip behavior of the BFRP bars in concrete with different strength grade.

\begin{tabular}{|c|c|c|c|c|c|}
\hline Corrosion age & Concrete strength & $\begin{array}{c}\tau_{1} \\
(\mathrm{MPa})\end{array}$ & $\begin{array}{c}s_{1} \\
(\mathrm{~mm})\end{array}$ & $\begin{array}{c}\tau_{2} \\
(\mathrm{MPa})\end{array}$ & $\begin{array}{c}s_{2} \\
(\mathrm{~mm})\end{array}$ \\
\hline \multirow{3}{*}{0 days } & C30 & 22.5 & 3.5 & 1.2 & 9.2 \\
\hline & $\mathrm{C} 40$ & 23.0 & 3.2 & 4.0 & 8.8 \\
\hline & C50 & 23.5 & 2.8 & 3.9 & 8.5 \\
\hline \multirow{3}{*}{90 days } & C30 & 21.5 & 3.1 & 1.1 & 10.0 \\
\hline & $\mathrm{C} 40$ & 22.4 & 2.6 & 3.8 & 8.2 \\
\hline & C50 & 22.6 & 2.2 & 4.4 & 7.9 \\
\hline
\end{tabular}

TABLE 6: The geometrical parameters of bond-slip behavior of BFRP bars in concrete according to improved BEP model.

\begin{tabular}{lccccc}
\hline Size of BFRP bars & Age of corrosion (days) & $A_{r}\left(\mathrm{~mm}^{2}\right)$ & $\alpha$ & $p$ & 0.042 \\
\hline \multirow{3}{*}{$\Phi \mathrm{mm}$} & 0 & 37.1 & 1.12 & 0.91 & 0.049 \\
& 60 & 31.5 & 23.1 & 0.73 & 0.040 \\
\hline \multirow{3}{*}{$\Phi 25 \mathrm{~mm}$} & 90 & 42.5 & 0.57 & 0.049 & 3.2 \\
& 0 & 28.1 & 0.78 & 0.039 & 3.7 \\
\hline
\end{tabular}

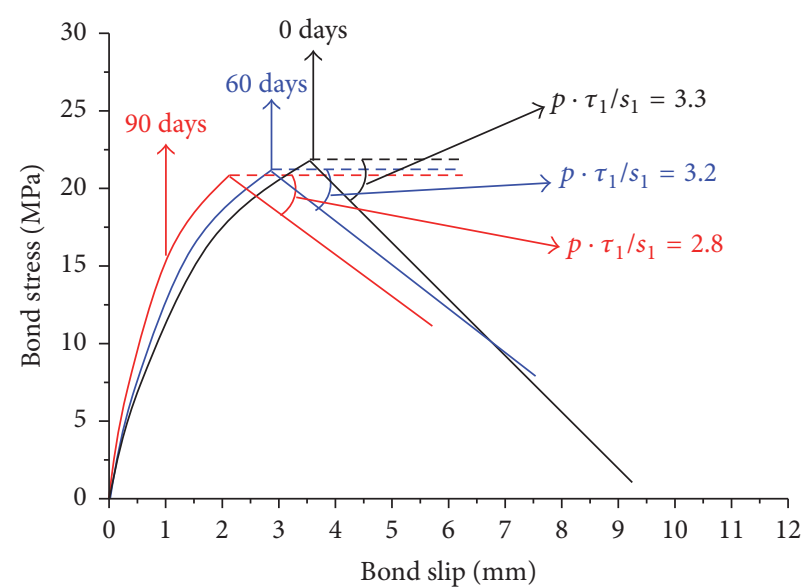

(a) $\Phi 8 \mathrm{~mm}$

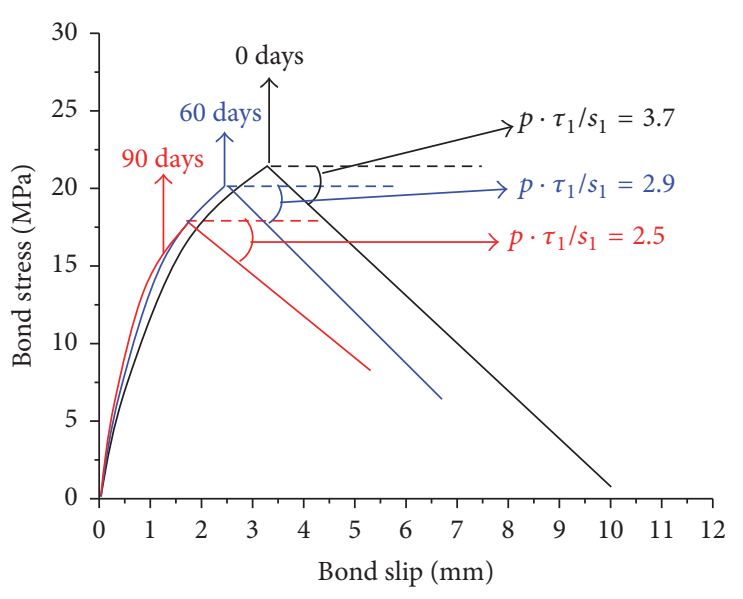

(b) $\Phi 25 \mathrm{~mm}$

FIGURE 10: Geometry of bond-slip behavior of BFRP bars in concrete according to improved BEP model. 
be softer after corrosion, and the corrosion has much more significant effect on the bond-slip behavior of large size BFRP bars in concrete.

\section{Conflicts of Interest}

The authors declare that they have no conflicts of interest.

\section{Acknowledgments}

This work was funded by National Key Research and Development Program (no. 2016YFB0303502), Water Conservancy Science and Technology of Guangdong Province of China (2015-10 and 2016-23) and the China Postdoctoral Science Foundation (no. 2016M590776). Their financial supports are gratefully acknowledged.

\section{References}

[1] X. Shi, N. Xie, K. Fortune, and J. Gong, "Durability of steel reinforced concrete in chloride environments: an overview," Construction and Building Materials, vol. 30, pp. 125-138, 2012.

[2] F. M. Al-Oqla and S. M. Sapuan, "Natural fiber reinforced polymer composites in industrial applications: feasibility of date palm fibers for sustainable automotive industry," Journal of Cleaner Production, vol. 66, pp. 347-354, 2014.

[3] J. G. Teng, T. Yu, and D. Fernando, "Strengthening of steel structures with fiber-reinforced polymer composites," Journal of Constructional Steel Research, vol. 78, pp. 131-143, 2012.

[4] D. A. Hensher, Fiber-Reinforced-Plastic (FRP) Reinforcement for Concrete Structures: Properties and Applications, vol. 42, Elsevier, 2016.

[5] P. Böer, L. Holliday, and T. H.-K. Kang, "Independent environmental effects on durability of fiber-reinforced polymer wraps in civil applications: a review," Construction and Building Materials, vol. 48, pp. 360-370, 2013.

[6] V. Lopresto, C. Leone, and I. De Iorio, "Mechanical characterisation of basalt fibre reinforced plastic," Composites Part B: Engineering, vol. 42, no. 4, pp. 717-723, 2011.

[7] A. Lapko and M. Urbański, "Experimental and theoretical analysis of deflections of concrete beams reinforced with basalt rebar," Archives of Civil and Mechanical Engineering, vol. 15, no. 1, pp. 223-230, 2015.

[8] X. Wang, G. Wu, Z. Wu, Z. Dong, and Q. Xie, "Evaluation of prestressed basalt fiber and hybrid fiber reinforced polymer tendons under marine environment," Materials and Design, vol. 64, pp. 721-728, 2014.

[9] J. D. Garcia-Espinel, D. Castro-Fresno, P. P. Gayo, and F. Ballester-Muñoz, "Effects of sea water environment on glass fiber reinforced plastic materials used for marine civil engineering constructions," Materials and Design, vol. 66, pp. 46-50, 2015.

[10] D. Borrie, H. B. Liu, X. L. Zhao, R. K. Singh Raman, and Y. Bai, "Bond durability of fatigued CFRP-steel double-lap joints preexposed to marine environment," Composite Structures, vol. 131, pp. 799-809, 2015.

[11] G. Wu, X. Wang, Z. Wu, Z. Dong, and Q. Xie, "Degradation of basalt FRP bars in alkaline environment," Science and Engineering of Composite Materials, vol. 22, no. 6, pp. 649-657, 2015.
[12] A. Altalmas, A. El Refai, and F. Abed, "Bond degradation of basalt fiber-reinforced polymer (BFRP) bars exposed to accelerated aging conditions," Construction and Building Materials, vol. 81, pp. 162-171, 2015.

[13] B. Tighiouart, B. Benmokrane, and D. Gao, "Investigation of bond in concrete member with fibre reinforced polymer (FRP) bars," Construction and Building Materials, vol. 12, no. 8, pp. 453-462, 1998.

[14] D. Shen, B. Ojha, X. Shi, H. Zhang, and J. Shen, "Bond stressslip relationship between basalt fiber-reinforced polymer bars and concrete using a pull-out test," Journal of Reinforced Plastics and Composites, vol. 35, no. 9, pp. 747-763, 2016.

[15] ACI Committee 440, Guide for the Design and Construction of Structural Concrete Reinforced with FRP Bars, American Concrete Institute, 2007.

[16] G. Wu, Z.-Q. Dong, X. Wang, Y. Zhu, and Z.-S. Wu, "Prediction of long-term performance and durability of BFRP bars under the combined effect of sustained load and corrosive solutions," Journal of Composites for Construction, vol. 19, no. 3, Article ID 4014058, 2015.

[17] R. A. Hawileh, H. A. Rasheed, J. A. Abdalla, and A. K. AlTamimi, "Behavior of reinforced concrete beams strengthened with externally bonded hybrid fiber reinforced polymer systems," Materials and Design, vol. 53, pp. 972-982, 2014.

[18] A. Serbescu, M. Guadagnini, and K. Pilakoutas, "Mechanical characterization of basalt FRP rebars and long-term strength predictive model," Journal of Composites for Construction, vol. 19, no. 2, 2015.

[19] A. El-Nemr, E. A. Ahmed, and B. Benmokrane, "Flexural behavior and serviceability of normal- and high-strength concrete beams reinforced with glass fiber-reinforced polymer bars," ACI Structural Journal, vol. 110, no. 6, pp. 1077-1087, 2013.

[20] X. Lin and Y. X. Zhang, "Evaluation of bond stress-slip models for FRP reinforcing bars in concrete," Composite Structures, vol. 107, no. 1, pp. 131-141, 2014.

[21] J. Shi, H. Zhu, Z. Wu, R. Seracino, and G. Wu, "Bond behavior between basalt fiber-reinforced polymer sheet and concrete substrate under the coupled effects of freeze-thaw cycling and sustained load," Journal of Composites for Construction, vol. 17, no. 4, pp. 530-542, 2013.

[22] H. Zhu, G. Wu, J. Shi, C. Liu, and X. He, "Digital image correlation measurement of the bond-slip relationship between fiber-reinforced polymer sheets and concrete substrate," Journal of Reinforced Plastics and Composites, vol. 33, no. 17, pp. 15901603, 2014.

[23] R. H. Haddad, R. Al-Rousan, and A. Almasry, "Bond-slip behavior between carbon fiber reinforced polymer sheets and heat-damaged concrete," Composites Part B: Engineering, vol. 45, no. 1, pp. 1049-1060, 2013.

[24] A. D’Ambrisi, L. Feo, and F. Focacci, "Experimental analysis on bond between PBO-FRCM strengthening materials and concrete," Composites Part B: Engineering, vol. 44, no. 1, pp. 524532, 2013.

[25] D. Yeboah, S. Taylor, D. McPolin, and R. Gilfillan, "Pull-out behaviour of axially loaded Basalt Fibre Reinforced Polymer (BFRP) rods bonded perpendicular to the grain of glulam elements," Construction and Building Materials, vol. 38, pp. $962-$ 969, 2013.

[26] ASTM, "Standard test method for tensile properties of polymer matrix composite materials," ASTM D3039/D3039M, ASTM International, West Conshohocken, Pa, USA, 2014. 
[27] ASTM, "Standard test method for compressive strength of cylindrical concrete specimens," ASTM C39/C39M, ASTM International, West Conshohocken, Pa, USA, 2016.

[28] A. Katz and N. Berman, "Modeling the effect of high temperature on the bond of FRP reinforcing bars to concrete," Cement and Concrete Composites, vol. 22, no. 6, pp. 433-443, 2000.

[29] ASTM, "Standard practice for the preparation of substitute ocean water," ASTM D1141, ASTM International, West Conshohocken, Pa, USA, 2013.

[30] ASTM, "Standard test method for bond strength of fiberreinforced polymer matrix composite bars to concrete by pullout testing," ASTM D7913/D7913M, ASTM International, West Conshohocken, Pa, USA, 2014.

[31] R. Eligehausen, E. P. Popov, and V. V. Bertero, Local Bond Stress-slip Relationships of Deformed Bars Under Generalized Excitations, University of California, Berkeley, Calif, USA, 1982.

[32] E. Cosenza, G. Manfredi, and R. Realfonzo, "Behavior and modeling of bond of FRP rebars to concrete," Journal of Composites for Construction, vol. 1, no. 2, pp. 40-51, 1997. 

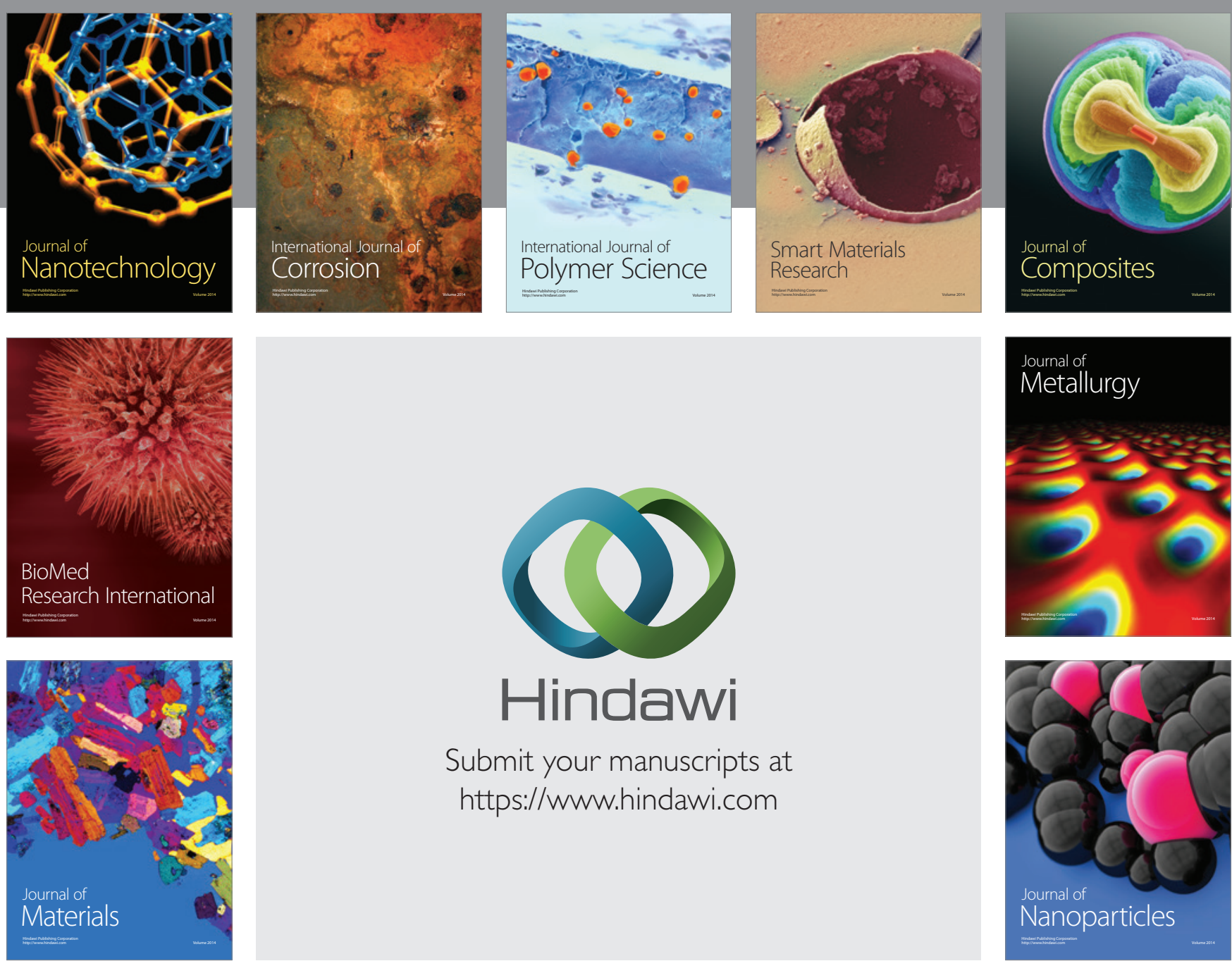

\section{Hindawi}

Submit your manuscripts at

https://www.hindawi.com

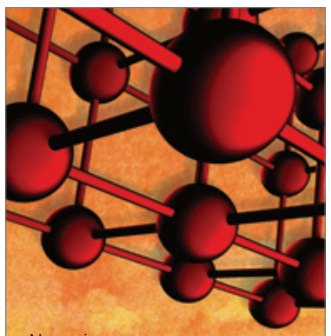

Materials Science and Engineering
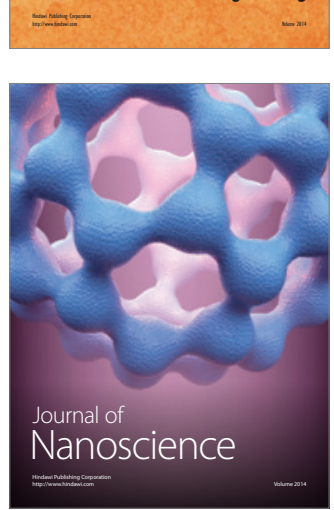
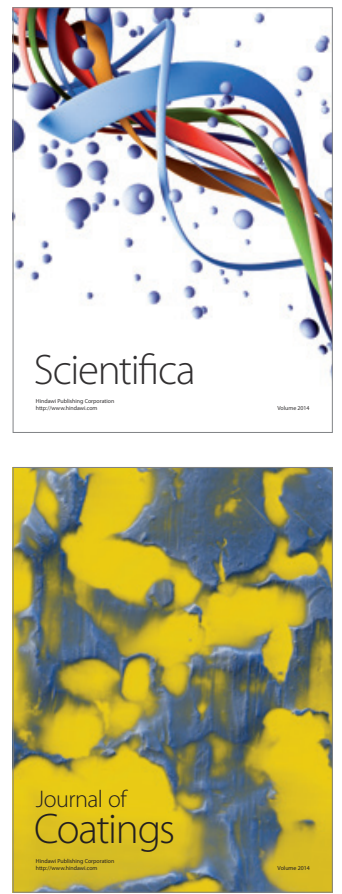
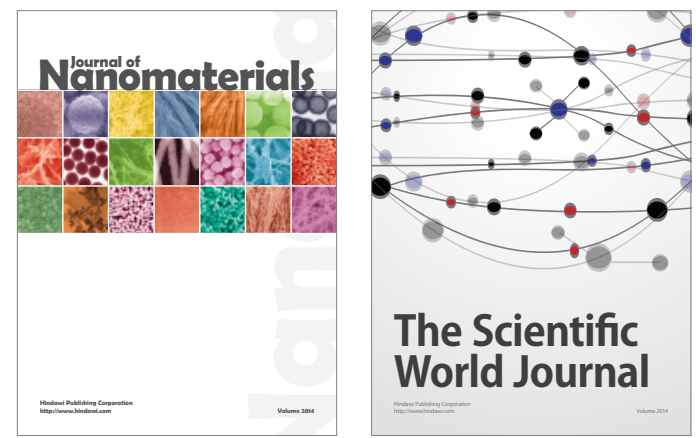

The Scientific World Journal
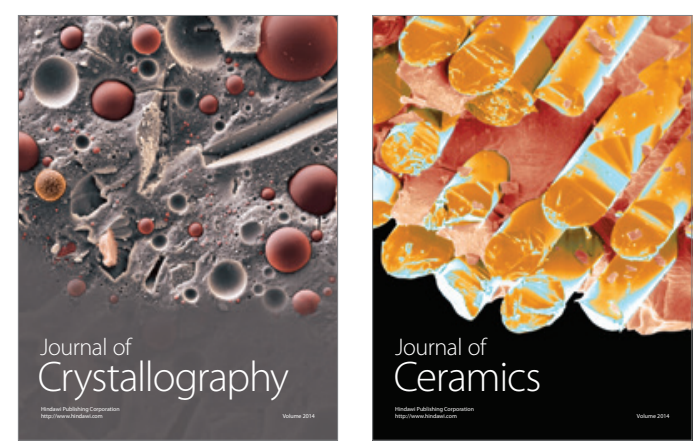
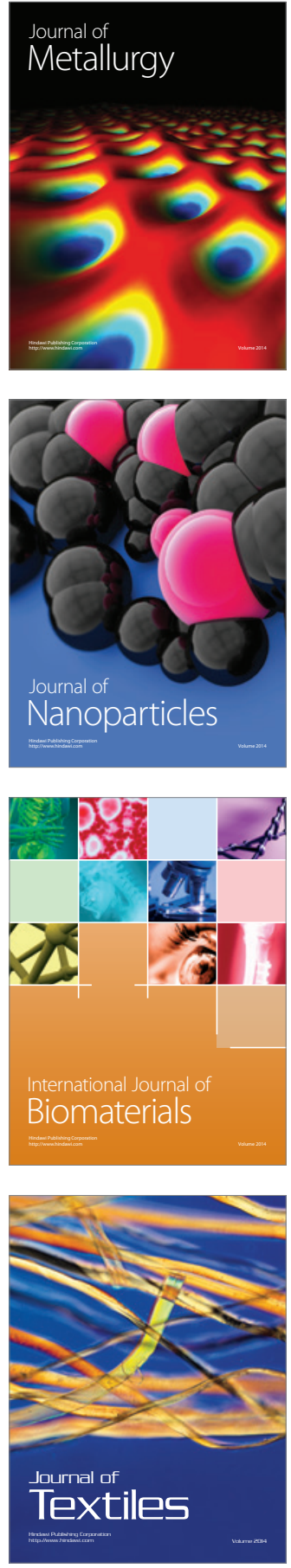